\title{
Here, there, and beyond: \\ remittances in transnational \\ family consumption
}

DOI: 10.22403/UQROOMX/TYP10/07

\author{
Lisa Peñaloza \\ EDHEC Business School, Lille France \\ Judith Cavazos Arroyo \\ Universidad Popular Autónoma del \\ Estado de Puebla
}

\section{Abstract}

This research charts the multicultural nature of remittances as they impact consumption in transnational families. Using interview data, it is emphasized the importance of remittances sent by migrant workers in the U.S. to their families in Mexico in a process of family reproduction that features consumption activities and events and cultural meanings that together affect these families. Analysis highlights the cultural meanings of family motivating members to leave home to procure remittances for consumption, even as doing so changes and challenges the very viability of these families. Theoretically, this work contributes to the knowledge of remittances in an intricate web of transnational, family consumption activities and meanings, and adds to understandings of the central role of consumption in the transnational family. The research is concluded with implications for consumer researchers and public agencies concerning the place of consumption in transnational family development and well-being. 


\section{Introduction}

Almost I 5 years ago, Ger and Belk (1996) mapped out the consumptionscapes of lesser developed nations, pointing to migration as one of several forces spurring global consumer culture together with marketization, tourism, media, popular culture, and cosmopolitanism. This work delves into the operational ways migration produces global consumer culture via remittances in consumption within transnational families.

Remittances are widespread and their cultural and political significance is profound, with estimates of over 300 billion dollars annually (British Broadcasting Corporation News, 2009) sent by roughly 200 million migrants in the world (Bertossi, 2008). In many nations, remittances exceed nation-tonation foreign aid by a factor of three (Lapper, 2007). The Mexican Central Bank totaled remittances of $\$ 25$ billion dollars sent by Mexicans working in the U.S. in 2008, a 3.6\% decrease from the previous year attributed to the recession (British Broadcasting Corporation News, 2009). In Mexico, one of five households depends on remittances (Suro, 2003), most of which are sent from the U.S. due to its higher level of development, proximity, and vibrant immigrant networks (Rouse, 1992; Smith, 2006).

The theoretical framework brings together previous research on transnationalism, consumer culture, and the family in developing countries for study. First, transnational studies are useful in conceptualizing the transnational domain in which these families inhabit. Monetary funds together with products, knowledge, and skills that migrant workers obtain in developed nations such as the U.S. bring vital economic, social, and cultural capital to developing nations such as Mexico that are characterized by limited economic opportunities (Suárez-Orozco,Todorova \& Louie, 2002). In making sense of migration, scholars emphasize a transnational domain not fully contained within either nation, one comprised of imagined representations and comparisons of each nation as well as the geographic space, sociolinguistic translations, and hybrid cultural forms flourishing between them (Rouse, 1992; Smith \& Guarnizo, 2002). Relevant are the cultural domains here in Mexico where family members live, there, in the U.S. where the migrant remittance sender lives, and beyond in the metaphorical and very real space between these nations through which emigrant workers and family members literally cycle in travel, remittances, and gifts, and figuratively in consumption dreams and desires. 
Second, scholars examining consumption that is transnational in scope emphasize the circulation of multicultural meanings and practices and mediated lifestyle standards and images in bringing about hybrid global-localized identities and consumption patterns (Peñaloza, 1994; Belk, Ger \& Askegaard, 2003; Askegaard, Arnould \& Kjeldgaard, 2005; Kjeldgaard \& Askgegaard, 2006; Üçok, 2007). This research builds upon these insights by examining consumption dynamics in transnational families. Consumption is a driving force in the migration separating these families pursuing a better life, even as the family and the transnational domain shape the contours and dynamics of such consumption.

Third, work on the transnational family provides crucial insights regarding how this geographically dispersed social group reproduces intimate relationships and life goals (Hirsch, 2003), identity, roles, and non-intimate relationships (Falicov, 2005). It is built upon these insights in focusing on the family as produced in consumption (Epp \& Price, 2008), with attention to the particularities of transnational circumstance.

This research pretends to answer the following research question: How do remittances sent from the U.S. (there) to Mexico impact the dynamic of transnational family consumption in Mexico (here) and beyond these two national domains?

\section{Conceptual Framework}

\section{Transnational Social Phenomena}

Insights from transnational scholarship emphasize the socio-economic conditions within particular national domains and the comparisons and imagined cultural realities between them. This work builds upon earlier debates in globalization studies regarding increasing homogenization simultaneous with increasing localization of cultures.

Smith and Guarnizo (2002) distinguish between transnationalism from above, a orientation which strives to make sense of the increasingly intense international flows of people, capital, and products and services as they impact nation-states, economic systems, and social structures; and transnationalism from below, a microorientation emphasizing how social beings negotiate and resist these flows in crafting identities and relationships. The mesoorientation 
draws from both in focusing on consumption activities in producing family, while not losing sight of macroglobal and national socio-economic forces and microlocalized personal interests and identity.

Important at the macrolevel are the impacts of government policies and national representations on migration and remittance flows. Government policies regarding access to jobs, citizenship, social benefits, currency exchanges, and gift transfers spur and inhibit migration (Galarza, 1964; Peñaloza, 1995; Drainville, 2002). As a major resource in developing nations and communities worldwide, migrant remittances are changing these nations and relationships between them (Kennedy \& Roudometof, 2002), which in turn potentially affect migrants' views of each. In Mexico, contributions to associations and clubs in fees and donations that develop infrastructure, fund religious/cultural events, and repair old people's homes, health centers, schools, roads, and churches (Papail, 2002; Smith, 2006) potentially institutionalize migration, with repercussions for family norms.

Important at the microlevel is how people assemble life trajectories within and across the two domains, playing one against the other simultaneously and sequentially in enacting their lives. In this sense, transnational family consumption is lived here, there and beyond. It entails more than members' lives here and there in the two nations; it transcends beyond both in the many comparisons, meanings and exchanges between them in hopes, fears, dreams and desires. In this sense, the mechanisms of imagined community (Anderson, I99I) are pluralized in the images and related emotions of life here, there, and beyond for family members, with the family viewed as the primary social structure organizing travel, remittances, phone calls, gifts between members, etc., and with attention to how the transnational domain impacts consumption within the family.

\section{Transnational Consumer Culture}

Consumer researchers have highlighted a number of factors pushing immigrants away from home and pulling them to other nations, mapped their characteristics, identity processes, and consumption behaviors in the new nation, and noted the importance of socio-economic differences, media networks, and social relations within and between nations (Oswald, 1999; Peñaloza, 1994;Aaskegaard, Arnould \& Kjeldgaard, 2005; Visconti, 2006; Üçok, 2007). Much of this work has focused on immigrants as individuals, with consumption emphasized as 
the means through which they take on a new national identity and way of life, maintain and enhance their previous ones, reject both (Peñaloza, 1994), swap (Oswald 1999) and alternate between the two (Visconti, 2006), and otherwise exhibit hybrid practices and meanings that resemble but are not reducible to the national cultural forms of their previous or new residence (Askegaard, Arnould \& Kjeldgaard, 2005). An exception is Lindridge, Hogg \& Shah's (2004) study emphasizing the importance of family by South Asian women in Britain dealing with consumption differences associated with the dual cultures.

In this work, consumption is an integral factor driving migration, and while it has long been noted as an important arena in which social relations are negotiated (Bourdieu, 1986; Holt, 1997), how consumption status is navigated transnationally is only beginning to be explored. As an example, Üçok (2007), noted different priorities and social hierarchies in explaining why many Turks live rather Spartan lives in Denmark, working and saving to fund their upper middle class existence in Turkey. Regarding this study of remittances in the family, accounting for cultural differences is crucial in consumption within and across the two national domains as negotiated by family members.

Remittances used for consumption likely impact social positions and priorities, although labor tends to be emphasized in much of the transnational scholarship.Thus it is built upon Goldring's (2002) insights that Mexican workers in the U.S. tend to inhabit social positions relatively more subordinated than theirs in Mexico where they gain status from working in the U.S. and sending remittances. The mesodesign explores how families access various forms of capital generated by members in the U.S. and integrate these resources into the Mexican cultural significatory system in consumption, with attention to the effects of such consumption on relations within their families and in their communities.

In attending to the "other side" of the family, those left behind, documenting their consumption and dissecting its cultural significance, this work complements and extends previous studies by Askegaard,Arnould \& Kjeldgaard (2005), Oswald (1999), Peñaloza (1994) andVisconti (2006), emphasizing immigrants as individuals and focusing on their lives in the country of immigration. This work is further distinguished from studies of dominated consumers within a nation (Üstüner \& Holt, 2007), as these families may gain status related to the remittances. In the next section we turn to work focused on the transnational family. 


\section{Transnational family}

Insights from this body of scholarship highlight how people forge emotional and economic ties in families of various forms, using various technologies and strategies to bridge the physical distances and socio-economic differences between where the migrant works and where the family resides (Bryceson \& Vuorela, 2002). Noteworthy are the ideals driving transnational family formation, with sacrifices and mixed payoffs as couples, children, and extended family members creatively love and seek to better their lives across distances of space and time. As examples, in her study of Ecuadorean and Peruvian migrants in Spain, Parella (2007) emphasizes the ways economic and emotional support and obligations bind migrants to nuclear and extended family members at home, and traces the mix of economic gain, changing tasks and gender roles, and feelings of abandonment and conflicts in couples and with children. Hirsch (2003) highlights changing ideals of romantic love, intimacy, childrearing, and material standards of living, as Mexican transnational couples emphasized companionship and egalitarianism, and distinguished themselves from the traditional, male-dominated relationships of their parents in Mexico.

The cultural adaption of migrants challenges relations with family members who remain at home in nuclear and extended forms. Parreñas (2005) contrasted the traditional gender roles of the guardians taking care of children who remained in the Philippines with the more modern gender roles of migrant parents. Smith (2006) noted more freedom of movement in the U.S. for teenage girls living in New York with their Mexican parents as compared to their time with extended family members in Mexico where their brothers and other family members enforced more restrictive, culturally appropriate behaviors for young women. While this work does not focus on consumption in these transnational families, because it highlights economic and emotional support, conflict, and adaptation related to differing cultural values and traditions, it is useful to explore how members act as transcultural arbiters reproducing family goals and traditions in consumption in Mexico with resources and values garnered in the U.S., and beyond in media images, feelings, meanings and their imagined comparisons of life and its translations between the two places. The cultural clashes and distance experienced by relatives makes it difficult for them to sustain transnational families over time and over generations (Castles \& Miller, 2003). 
Consumption is viewed in this research as the means through which family members enact important dimensions of their identity and relations with others in stories and rituals (Epp \& Price, 2008). Previous work has shown the importance of consumption in divorced families dealing with physical separation (Bates \& Gentry, 1994) and in bicultural families dealing with divergent cultural values and traditions (Cross, 2008). This work differs from this somewhat in examining consumption dynamics in families trying to stay together across geographical distances here, there and beyond and for whom respective transnational cultural differences are initiated as members generate remittances.

Consumption serves as an important site for the production of family relations in migrant families remaining in the home country. Schmalzbaur (2005) draws attention to consumption in motivating migrants to leave Honduras to seek work to send back money to better the lives of family members, in ways similar to those noted by Hirsch (2003) in Mexican transnational families. Kalir (2005) described the lavish spending of families and communities for parties welcoming back Ecuadoran migrants from Israel. Consumption thus appears to pull emigrating family members away in securing resources to advance the lives of family members, with such migration celebrated in the community.

Migration is conceptualized in this article as a cultural ritual and rite of passage for social mobility anchored in consumption and practiced by families in community with other families, with movements in time and space metonymically designating a better way of life. In the transnational cultural domain, consumption may ground and dislocate family members in reinforcing, testing, and otherwise acting upon them and their relations with each other as they forge "the good life". As an example, Üçok (2007) noted parents' lives anchored primarily in Turkey, whereas their youth meandered between the two nations in finding their places, with most opting for Danish life, although a few returned to Turkey. Extrapolating from Kjeldgaard and Askegaard's (2006) recognition of global similarities between young Danes and Greenlanders as part of a globalized youth culture that did not resemble either Greenlander or Danish cultures, migrant families may have more in common with each other than with their counterparts without migrant members. 


\section{Research Design}

The research design entails in-depth interviews with ten persons living in seven families in Mexico who have an immediate relative working in the United States and receive money from that person. Per Consumer Culture Theory [CCT] conventions and those in cultural studies regarding theoretical/epistemological sampling (Hirsch, 2003; Sherry \& Fischer, 2009), variation was sought in meanings and strategies regarding the phenomena in question, in this case, variation in gender, age, social class, worker and family characteristics, context, education, and the rate of migration in the area of residence (Table I). Three interviews were conducted in major urban areas, three in small cities, and four in rural areas from two states in central Mexico, Puebla and Tlaxcala, as these states represent migration rates of medium intensity (Conapo, 2000).

Interview questions began with daily life in Mexico, continued with consumption of products and services, and then proceeded through family and community activities and events. Then, the interview inquired specifically about family members working in the U.S.: what they do and how often they communicate and visit, before ultimately turning to the types of items and amounts of money they send and its uses and significance to family members and in the community in Mexico.

In carrying out the analysis, data were organized into summary form, from which categories of agents were developed: (i.e. migrant, family, friends, neighbors and municipality), relations (wife, parent, sibling), and consumption activities (healthcare, birthdays, homebuilding). Then patterns were derived within the categories and relations between them (Lofland et al., 2006). Meanings were discerned in various consumption activities, the processes through which members move skills and resources across national cultural domains and incorporate them in Mexico, and the impacts on the families.

\section{Empirical Account: Family Consumption Here, There, and Beyond}

During the analysis, different aspects emerged that impact the Mexican transnational family consumption: the spatial, temporal and social dimensions during the trajectories, activities and household consumption decisions which are supported by remittances, processes and meanings as well as the impacts in family members, community and public agencies (Figure I). 


\section{I, Spatial,Temporal, and Social Dimensions and Trajectories of Migration}

Mexican families with migrant workers in the United States transcend national boundaries in their love, obligations, and interactions with each other, and it is within these bi-national, socio-cultural, and economic social groups that their consumption is intelligible. In this section are detailed temporal, spatial, and social dimensions in informants' accounts of their attempts, successes, and failures reconciling disparate standards of life and ideals within and across the dual national domains and juxtaposing them in consumption.

Social webs stimulate and support migration. Family members discuss, act upon, and alter their goals and responsibilities with explicit consideration of the unemployment and a lower standard of living in Mexico they contrast with higher job opportunities and standards of living in the United States. In her interview, Tania Álvarez describes the first time her brother went to the U.S, "Before, he worked at the ranch and obtained very little money. Then someone invited him to go and he went, but he came back defeated the first time, and later went again".

Previous work detailing the consumer acculturation of immigrants and their descendents has mentioned these networks, yet has emphasized how the individual makes basic living arrangements and adjusts to market and social life in hybrid consumption patterns of the present and former country and global cultural variations (Peñaloza, 1994; Oswald, 1999; Askegaard, Arnould \& Kjeldgaard, 2005). To these personal cultural challenges and adaptations, the account of transnational family consumption adds the grave responsibilities and rewards of family, the encouragement and criticism of others, the incidence of costly trips back and forth for pleasure and duty, and distinctions between the heroic returns of those who succeed and the despondent returns of those who do not.

Emigrants leave Mexico for the U.S. in a series of intensely emotional family negotiations. It was found that trust, dedication, sense of destiny and religiosity are present feelings in family members at leaving. In moving, the migrant and his/her family separate physically and emotionally, sacrificing family unity for the prospect of a better future together. In Mexico specifically, ambitions and desires for a better life fueled by mediated and imagined representations of the U.S., anticipated earnings, and witness of others' possessions in Mexico together contribute to what we characterize as a consumption "war" economy. 
Consumption contestations in cultural traditions and values constitute the battles. Like military operations fought in other nations, most men in their productive years leave to procure resources for consumption, leaving in their wake a society predominantly populated by women and by the old and young.

\section{Activities}

\section{Receiving Remittances. Amounts and Timing}

Family member and household characteristics impinge upon the amount of money sent by Mexican migrant workers (Figure I). First among these are the sociodemographic characteristics and time in the U.S. for workers, as they establish and in some cases reestablish their work and living situations in the U.S. While some are fortunate to have employers who understand their transnational family circumstances; others do not, and must reestablish their jobs or find new ones upon their return.

Demographics for the receiving family members and migrant senders then become important. Most migrant family members are men, although the numbers of women are increasing due to familial needs, job opportunities, and changing gender roles. Those who leave tend to be young adults, and the range of their class status tends to widen with the extent of economic difficulties in Mexico.

Remittance amounts ranged from a high of $\$ 2500$ to $\$ 2700$ dollars per month to lows of $\$ 10$. For wife and children recipients the totals tend to be higher and more frequent than for parents or siblings. Further, the former contributions tend to be considered as basic obligations, while the latter are considered gifts. Elderly women were most accepting and supportive of family members leaving to work in the U.S., especially those experiencing deprivation or hardship in their lives related to health.

Interviewees used several types of businesses, depending on their speed, security, and convenience, to receive remittances from family members in the U.S. Most receivers go to banks and exchange offices, although some, like Maria Rodriguez who prefers to go to "envíos," smaller locations closer to their homes. As she notes, the companies ask whether she wants her remittances in dollars or pesos and then give them to her. 


\section{Consumption Timing and Allocations}

Short, medium and long term. Family members in Mexico allocate remittances in the short, medium, and long term. Those asking for remittances in pesos tend to receive smaller amounts for use in day-to-day foods and toiletries, while those receiving "envíos" in dollars tend to save them for mid and longer term spending. Currency savings in pesos were uncommon due to mistrust of banks and high inflation.

In the short and mid term, receivers, most of those interviewed being housewives, manage the money for regular use in products and services related to communication, education, clothing, electronics, and food, as well as health emergencies, and these allocations tend to be influenced by the migrant. In the following excerpt Gabriela Moreno refers to short, medium, and long term provisions of food, health care, and house building, all made possible by money sent from her sons, "They send money for food and illness. When they went to the United States I said, you are going, but you should build a house here and they have all built their houses. When I was sick they sent money for my four surgeries."

Interviewees used remittances in the mid term for vehicles, health care and loans of money; and in the long term for building homes and setting up businesses. In Mexico, as in other parts of the world, remittances spent to build houses simultaneously serve as consumption in furnishing a dwelling to live in, as savings for family security, and as an investment in generating wealth for the family's future, with members continuously updating, modifying, and decorating their houses. This multiple use cuts across economists' categorical divisions between consumption, saving, and investment, and factors into the subsequent analysis of the impacts of remittances on the quality of family life, their happiness, wealth, and financial security.

Notably, family expenditures for mid and long term usage in buying a car or land, loaning money, building a home, or starting a business temper short term consumption. Family money managers in Mexico, most of whom are women, tend to be frugal in their spending, saving to help their loved ones return home sooner.

Rebecca Salas' strategy is to divide her earnings from her husband's, using her wages for everyday expenses and saving his for their long term goals in building a house and his return. As she says, "I keep it all in dollars. What he 
sends I try not to touch. That is, what he sends is to save, save, save, and then I use what I make here (in Mexico) for our regular household expenses."

Regarding use of the phone, informants noted that migrant family members working in the U.S. tended to call them weekly using a prepaid card. Some interviewed in rural areas use public phone booths, "casetas," to receive the calls. When an emigrant called, a microphone announced the name of the receiver to come take the call. Others used fixed telephone lines and cell phones.Wives reported using the phone to discuss personal and family household issues and activities, such as taking care of children or discussing expenses related to the house or business. For family members telephone technology gives vital access to daily life, maintains relations with spouses, children, and parents, and serves as the mechanism for participating in family consumption.

Family events and gatherings such as weddings, births and birthdays, illnesses, funerals, and holidays are primary among the reasons for trips back. Migrants travel regularly to take care of family members, houses, personal affairs, such as paying taxes, making major purchases, and establishing and checking on businesses they had set up in Mexico. Trips back thus entail much work reconnecting the migrant to his/her family members and helping fulfill family obligations and responsibilities. In the following quote Tania Álvarez relates her brother's packed itinerary. "One day for taxes, another to settle my affairs, two days for my father and mother, two days for my in-laws." Some special trips could be required. In family crisis or business emergencies, the migrant does not have advance notice in scheduling travel. S/he returns, depending on the gravity, the costs, and work commitments.

Amidst these trials and tribulations, a key event celebrating migrants' return is the "comida de bienvenida" (welcome back luncheon). Timing is essential, as short term returns can be considered failures. The length of time for the return varies as well, from permanent ones to those of short duration. In the case of emigrants who have been away a long time and have made substantial contributions to family members, friends, and/or the community, the celebration can span several weeks. Family members and close friends gather to honor the return of the migrant and share special foods and beverages typical to the area. We build upon Kalir's (2005) work focusing on the importance of these parties for the migrant disposition, instead highlighting their importance as ritualized consumption events in which the family and community express appreciation 
to the migrant, and in turn s/he presents clothes, electronics, and money to family members, close relatives, and friends.

Products. Migrants bring products from the U.S. and distribute them within networks of relatives and friends and in the village or metropolitan community in Mexico. Returning migrants bring the products, as mentioned above; at other times they send them via another person who often extends the network beyond the family to acquaintances or commercial providers. Using "envíos" can be expensive when paid in terms of weight, and usually the relative working in the United States is the one to pay.

The circulation and use of products assemble cultural meanings of family by reinforcing social relations, satisfying obligations or showing appreciation for those filling in for their responsibility while gone, building status, and demonstrating cultural skills and knowledge. As examples, gifts to spouses reinforce marital love and commitment, while birthday gifts reinstate parental relations with children. Products brought from the U.S. help compensate for absence, in the case of a gift from a migrant brother to his sister in acknowledging her care for their elderly parent. Such products afford status as well, as children with brand name clothes and caps are seen in the village. Finally, products are a way in which returning migrants share their new tastes, in the case of specialty foods or music.

In the quote below, Tania Álvarez lists the most valued products: electronic devices, brand name clothes, and sports jerseys. Those who receive the items consider others to be envious, while those not receiving items consider those who do to be selfish.

The things they bring most often are clothes, cell phones, more than that, Discmans. Now you see a child using a Discman or backpacks, shoes, sports shoes with recognized brands. Hats and caps. Mostly they are those caps like fishing hats and they are the recognized brands. Here in town you see children with GAP pants and with Tommy Hilfiger caps. You see a lot of Timberland and Sony Discman.

Possession and utilization of these products is valued by recipients as resources for pleasure and status and by senders in maintaining relations with those at home. The alterations in status Rouse (1992) noted for migrant workers in the U.S. are transferred to Mexico, providing some of the advantages to family members previously reserved for those of higher status within the 
respective communities in Mexico. Because these items are valued within the family and community, they stimulate further migration. Young adults and teens, especially, spoke of the value of the products they had received from family members working in the U.S., closely followed by their hopes to eventually go to the U.S.

Foods listed by family members in Mexico included jam, mayonnaise, instant coffee, and butter. As Peñaloza (1994) noted, immigrants in the United States reported eating mostly typically Mexican food when they lived in Mexico, and incorporated foods associated with the U.S. and other nations slowly and steadily in the U.S. Those remaining in Mexico, like Tania Álvarez and her family, learned to eat new foods brought by family members. Upon her brother's return to the United States, Tania remembered asking herself: "Why can they eat these things and I can't?", as she added these items to her grocery list.

Conversely, family members in Mexico send to relatives in the United Stated typical foods from their region, as remembrances of them and home. In some cases, the gifts convey what is not available or accessible, although marketers increasingly provide items. Raquel Salas sent medicines to her husband, who refused to see a doctor in the United States due to the higher costs of health care there.

Investments in businesses. In a few cases migrants initiated businesses with family members and/or friends in Mexico. Challenges of readapting to life in Mexico add to those of starting and running the businesses. Below, José Villa relates his brother's business activity and eventual return to the U.S.

Then he was working with my brother in law, he has buses, they together looked into managing them. It was public transportation here in Puebla. He was looking at those things, he was trying to adapt to the life here, but I saw he couldn't. Another time he wanted to work with his taxi, that's the reason he bought the car, and he was in his last occupation related to public transportation, but he couldn't adapt very well (in Mexico) and he decided to go back (to the U.S.). He tried to establish a business, but he gave up.

Community Activities. That families are embedded in communities is evident in remittance allocations. In some areas it is common for migrants to send money for civic and religious positions that bring honor and status to the family. For 
example, a "mayordomía" (community religious leader) contributes money or expertise for celebrations and religious events, for the care of the church, and for an annual dinner at their house. José Villa explained that many mayordomos reside in the U.S. and that it was common for migrants to send money for the "Fiesta del Pueblo," (town celebration) held each year. Remittances shared with the community yield status to the family and fund community development. Smith (2006) emphasizes the increasing importance of these funds in taking the place of nation-to nation aid as remittances help fund schools, government buildings, and public services, such as education, health care, and transportation.

\section{Processes and meanings}

In accounting for the workings of the above activities in families, we derived processes and meanings of transnational family consumption. Processes include resource generation, translation, integration, and conflict. Initiating the process is the migration of one family member to another nation for purposes of generating money for other family members remaining at home. Subsequently, members translate capital - money, products, and ideas - from the national cultural domain in the U.S. to the other in Mexico in a process of juxtapositions, comparisons, and exchanges of meanings and values that extend beyond these two domains in an amalgam of hopes, fears, dreams, and desires of what (still) might be for these families, often despite their current circumstance. Integration involves the systematic consolidation of these resources in realizing family goals and ideals in extended and nuclear forms. Such integration is often characterized by conflict, yet has an elastic, resilient quality, as family members deploy these resources in consumption that in turn affects them in a myriad of ways.

Regarding meanings, they are different at the personal, familial and community levels, even their interlocutions. For individual family members, remittances encapsulate the rewards of a personal quest for resources and life meanings rife with growth and setbacks. Evident in discussions of departure, separation, and return are adaptations over time and in various circumstances, and dilemmas about responsibilities and commitments. At the level of the family, meanings of love/intimacy, togetherness even at a distance, care giving, sharing resources, and compromising for security, well-being, and happiness are fundamental. For communities, consumption cements connections with others and anchors the family home in Mexico. 


\section{4, Impacts of Transnational Family Consumption}

The capital, products, and ideas that Mexican migrant workers in the U.S. bring and send to their families in Mexico impact the family in many ways. Family members use the capital to consume, save, and invest, with key overlaps between these categories. Informants consume in ways that realize and alter their roles and lifestyles within the household and their relationships with others in the extended family and community.

Challenges of Producing Spatio-Temporally Distanced Family. Overall, informants conveyed the general sense in Mexico that to have a friend or a relative in the United States was considered the key to a better life, with the migrant readily acknowledged as heroic provider by those beneficiaries at home. While the data of this research supported this commonly held belief somewhat, the experiences of informants living in a transnational family were much more nuanced and bittersweet.

Migration stimulates comparisons between nations. Raquel Salas said she believed it was easier for people who go to the United States to make money than it was in her town, although she added that her husband is always talking about coming back. Guadalupe Reyes considered life in Mexico freer than that in the U.S., saying "Well, in Mexico it is like, you're freer, you know? You're freer because here nobody tells what to do." These family members consider the U.S. more powerful, intelligent and economically accomplished than Mexico, even as they perceived their lives in Mexico to be freer, in an ironic twist on the equation of development with freedom (Peñaloza, 1994; Sen, 1999).

Most informants held that migration improved the quality of their lives, despite the sacrifice of family union. Eight of the interviewed considered the final balance of migration to be positive in financial security and health. Common were expressions like that of Guadalupe Reyes, "My economic situation has improved”, Laura López,“I am not lacking money,” and Tania Álvarez, “We have been able to improve my mom's health."

However, these economic improvements did not appear to fully compensate for losses in weakened or severed family ties. Some informants lamented the erosion of family unity resulting from missed events. In describing the series of remittances sent by her brothers from the U.S to build their houses, Tania Álvarez's sister summed it up, "they built very beautiful houses, but they are 
empty. So, to me it doesn't make sense to build a house, obtain money and in the end stay in the U.S."

Relationships with children also are strained, and while talking regularly on the telephone helps, such tech-mediated authority appears to be a pale substitute for face-to-face contact in encouraging and disciplining positive outcomes with sons and daughters. Notes Rebeca Salas,"I have lost because he isn't with me, he doesn't help raise our son. The boy behaves badly because he knows his father isn't there and he does what he wants".

Extended family members reported strained relations as well. Initially, they welcomed back these heroic breadwinners, sharing stories of adventure, suffering, and triumph in ways that facilitate and strengthen family similar to narratives noted by Epp \& Price (2008). However, informants also reported family tensions and conflicts related to cultural differences and changes in values and priorities, intense jealousy or other emotions triggered upon their return, inappropriate behavior on the part of those left behind, and awkward or partial returns to previous household roles and behaviors. Noted Tania Álvarez about the return of her siblings, "when they come back, the attitude of my parents towards them bothers me. Well, it is not really jealousy; it's just that I feel my parents don't value me anymore."

Changes in Family Activities and Gender Roles. Families adapt to migrants' absence and their transmission of resources in many ways. In some cases, housing was reorganized. Rebeca Salas reported living with a friend when her husband returned to the U.S. to work. Gender roles were relocated, yet retained some traditional elements. The eight women interviewed reported carrying out the activities of the absent men in their lives, taking on traditionally male activities in disciplining children and building and managing property, while assuming even more active roles in everyday consumption decisions and practices, such as shopping, cooking, housecleaning, childcare, managing the household budget for the present, and caring for parents or in-laws. The converse did not hold for men remaining in Mexico. Raúl Ramírez and José Villa maintained a very limited role regarding everyday household consumption decisions and activities in their families.

Intriguing dynamics of transnational contact, conflict, and power in these families were observed. Family members remaining in Mexico were quick to note changes in the migrants upon viewing photographs or seeing and 
interacting with them in person upon their return. Some of these changes involved food and diet, while others related to tastes in music, manners of dress, and ways of speaking.

Consuming differently in living two ways of life is a marked feature of immigration (Peñaloza, 1994; Oswald, 1999; Askegaard, Arnould \& Kjeldgaard, 2005; Visconti, 2006; Üçock, 2007) and Mexicans in the U.S. This work was extended in elaborating mechanisms of transcultural authority and power in consumption as family members remaining in Mexico deal with the migrants upon their return. Important here are the changes that those who come back and those who remain notice in each other and how they regulate each other culturally. In giving positive and negative feedback to the emigrant, in expressing their approval and disapproval, family members and friends exert cultural pressure. For example, in noting changes in weight, appearance, demeanor, and comportment, both emigrants and family members apply and contest cultural principles in the attempt - at times conscious, at times less so- to mold each other's consumption to their particular cultural standards. Notably, these standards are not limited to the cultures here and there, as Mexican and U.S. cultures of consumption change over time, as imaginings and comparisons of life in the two places exceeds both domains into the catchall domain described as transnational.

Subsequent cultural dynamics of familial power are detected in whether the migrant continues with the changes, demonstrating knowledge of U.S. culture in Mexico; returns to his/her former characteristics and consumption patterns from when s/he lived in Mexico in demonstrating cultural resilience or familial deference; and/or exhibits combinations of the above.Arbitrating such power is the importance of the changes, relations between those giving and receiving the feedback, and the spatial location, as the migrant may arrest the changes while back in Mexico, only to return to his/her comportment upon returning to the U.S. Conversely, family members at times welcome the changes, incorporating the various aspects of such consumption in "bettering" their lives, even as the process challenges all.

Ultimately the changes here, there and beyond are too much for some families to bear. Returning to the cultural calculus, even for those families producing capital well beyond the costs of remittances, travel, phone, gifts, etc., the cultural meanings of such consumption may not successfully produce a 
healthy family. While most migrants intended to return to Mexico to live, and many did build houses and start businesses, as many ultimately returned to the U.S. While most families remained together at the time of the interview, in a few families life had simply moved on for members in Mexico, as the lives they had become accustomed to no longer left a place for the distant member. Interviewees in some families blamed changes in the migrant for making life difficult for them and straining the family union, even as they had agreed to separate to better their lives.

Community Relations and Development. Remittances routed to community events, activities, organizations, and infrastructure. Such allocations reflect and reconfigure the social position of families in their communities, and generate a range of appreciation and status. The magnitude of this honor is measured in the scale of the contributions, that of the house and its furnishings, the meals, and guest appearances at the community celebrations that together impact the social standing of the family.

Despite describing some gains in status with consumption and community investments, most interviewees lamented that migrants did not transfer to their families and communities more of the skills and knowledge they had gained in their experiences in the U.S. Tania Álvarez noted "It is better economically, but people remain dirty, migrants who come back do not transmit aspects that could be learned from the Americans." Reflecting upon the reasons for this lack of transfer, some interviewees, like José, blamed continued migration, "Many young people are just waiting for an opportunity to migrate to the United States, abandoning school here."

Bourdieu (1986) and Holt (1997) have written extensively on the transfers between economic, social, and cultural capital in education and consumption, respectively, which we extend to transnational families. We agree with informants that the ongoing appeal of El Norte is at least partly responsible for an ongoing brain and muscle drain in Mexico.The jobs and higher levels of consumption and lifestyle standards which continually revitalize representations of the U.S. in Mexico are dramatically more attractive in comparison to the lack of jobs and lower levels of consumption in Mexico. Yet we also attribute difficulties integrating various forms of capital in Mexico to the microdynamics of consumption authority and power demonstrated in the transnational families. Family members' ridicule and refusal of changes they notice in migrants' consumption collectively limit such integration. 
Ultimately transnational family consumption acts upon members' sensibilities in shifting orientations of social space and time and formulating hopes for the future. Thoroughly multiculturalized expressions of personal and familial strivings and activities informed here, there, and beyond in consumption impact people's sense of what can and cannot be done for themselves and their communities in Mexico. Virtually all interviewed bemoaned the lacks and inadequacies in Mexico while exalting the efficiency and higher consumption standards of living in the U.S. Arrangements through which migrants and their families contribute to community and religious events, organizations, and infrastructure reposition the family in the community and serve to diffuse responsibilities for local and federal government, foster international dependencies, and sustain the ever powerful myth of El Norte.

\section{Discussion}

Discussion works to unravel the disparate workings of transnational domains, consumption, and family in order to better understand the ways they come together in the lives of the people studied.Transnational cultural domains are useful in articulating the dynamics of global consumer culture while attending to particular localizations of sending and receiving between pairs of nations. The transnational domain stirs the restless quality of desire (Belk, Ger \&Askegaard, 2003) among the informants that propels further migration, with a feedback loop redefining Mexico and the U.S.

The ways socio-economic differences between Mexico and the U.S. foster a transnational space of aspirations, juxtapositions, and comparisons for migrants and their family members in ways that exceed representations of both nations and affect them. Like in many developing nations, the Mexican government is fostering the reproduction of transnational subjects because they generate such vast amounts of financial and other resources vital for development, even as doing so highlights shortcomings at home. In the U.S., as in other developed countries, the national government is caught between accommodating Mexican workers as vital sources of labor and consumption, while appeasing citizens who feel threatened by their presence.

Consumption continues as a major driving force in bringing about the transnational space that at the same time transforms such consumption. It was 
noted the many impressive ideals, sacrifices, and compromises characterizing the consumption of transnational families that arise within and cut across the dual national domains, as family members weighed their experiences of limited labor and consumption realities in Mexico against their hopes and dreams of greater labor and consumption possibilities in El Norte. Like them, countless other family members traverse parallel boundaries between other developing and developed nations across the globe. Their consumption dreams move in synch with labor opportunities that rise and fall in economic expansion and recession, with realizations of these dreams and opportunities played out in microcultural interactions and stereotypes that are inflected by, and yet change, longstanding macrorelations between the nations (Smith \& Guarnizo, 2002; Schmalzbauer, 2005; Parella, 2007; Üçock, 2007).

The positive impacts of consumption is credited in compensating for absent migrant members, in serving as a mechanism for achieving many basic family activities in providing funds for food, accommodations, and health care, and in enhancing no less important ethereal qualities of life in realizing hopes and desires for the increasing prevalence and cultural sanction of the transnational family in form and ritual in Mexico. In form, transnational consumption encourages and reinforces extended family structures. In ritual, such consumption is institutionalized in mutual obligation, support, and celebration. Family members' ambitious ideals of what couples can accomplish apart in increased earnings for enhancing consumption at home while maintaining trust and intimacy is highlighted; their beliefs about what their families should look like and displayed in their accounts of interactions in couples, with children, with parents, and with other family members, friends, and the community.These meanings and the processes they put in place impact transnational family consumption in a mosaic of realized and shattered hopes, dreams, and relationships, and sentiments ranging from security, well-being, and happiness to resentment, jealousy, and betrayal.

Findings showed that sacrifice and provisioning in transnational family consumption simultaneously strengthens and weakens family ties. In shedding light on family-making in consumption across national borders, this work dovetails with Miller's (1998) study of provisioning and sacrifice in shopping in the U.K., and advances novel elements. Members are strongly encouraged to leave to generate funds for the consumption of those at home, and doing 
so reinforces relations between recipients and providers. Even so, their relationships are continually tested here, there and beyond, in the geographical distances and cultural differences challenging family members, compounded by the recognition that things here aren't quite as good as things there, hoping that one day they could be, and living apart to help make them so.

Transnational family consumption reflects and modifies cultural notions of gender in family conduct as well. For men, such reflections and modifications relate to what it means to be a bread earner, father, and heroic provider in fulfilling family responsibilities crossing the frontier to bring back valuable money, objects, and ideas. For women, ideals of staying at home to mother children are slowly giving way to acceptance that wives and mothers make the trek north. In both cases, gender roles change as women, and to a lesser degree men scramble to cover tasks of shopping, cooking, parenting, house maintenance and building, and negotiating family obligations in the community, as they pick up activities performed previously by absent members. These changes ripple through the strata of young and old throughout Mexico, ultimately transforming the structure of these families in favor of extended arrangements and altering more general cultural ideals and practices regarding gender-appropriate behavior.

\section{Implications, limitations, and Suggestions for Further Research}

Implications of this work are theoretical and practical. The first implication extends from findings detailing transnational family consumption patterns as a complex and dynamic multicultural calculus of here, there, and beyond that is altering family forms and traditions in Mexico as a nexus of institutionalized migration and global consumer culture. It is suggested updates to critical understandings of consumption in the migrant family, not as an aberrant form of consumption, but rather as a global exemplar emerging as the result of contemporary socio-economic forces in the information age in ways parallel to the nuclear family that preceded it stemmed from fundamental socio-economic transformations associated with the industrial revolution (Poster, 1978). As such, the role of consumption in family building comes to the fore, weighing in with labor/occupation if not assuming preeminence over it, with idealized and 
romanticized qualities and ideological functions in developing nations parallel to those for the individual in developed nations.

As with other forms of global consumer culture, such as that of cosmopolitans (Thompson \& Tambyah, 1999) and youth (Kjeldgaard \& Askegaard, 2006), the migrant family may have more in common with other migrant families in Mexico than with families not comprised of a migrant member living there. The second implication deals with the potential cultural consequences as this social grouping is institutionalized, anchored as it is in adherence to transnational work and consumption. Ultimately, transnational families are the foot soldiers in this consumption war economy. It is consumption that migrants ultimately seek and attain, moving to another nation to work and send home remittances and gifts that make a better life for their families. At the same time, they enact important parts of the global economy in producing global consumer culture along with the agents and forces of marketization, tourism, media, popular culture, cosmopolitans, and corporations listed by Ger and Belk (1996).

The third implication extends from findings documenting how consumption in the Mexican transnational family is here, there, and beyond to suggest future implications stemming from the increasingly scattered global hegemonies (Grewal \& Kaplan, 1994; Mahler, 2002) it leaves in its wake.The global economy is such that increasing numbers of contemporary families include members who live in another nation because that is where they find better terms for work, not as an end in itself nor for them as individuals, but as the means to a better life for their families.Accomplishing such consumption advancements challenge models of status predicated on self-contained nation-states, replacing them with status negotiations in multiple, layered transnational domains in which workers subordinated or disenfranchised in Mexico gain access to capital in the U.S. that elevates the statuses of their families somewhat, potentially altering status systems in both nations.

Finally, this research contributes to practical strategies for more explicitly managing transnational consumption to advance family wellbeing in family counseling programs, in the schools, and in other government and nonprofit aid agencies. For couples, for example, programs giving guidance in balancing tradeoffs in short and long term consumption and working through reallocations of consumption activities and reconfigured gender roles is useful. Also recommended are programs to enhance transnational family members 
juggling immediate matters of food and health care bills for children and parents with maintaining intimate relations, saving, and home building to bring members home sooner. Differences in class, gender, and rural versus urban family life standards are relevant considerations, in taking into account adjustment to multiple levels of life standards and aspirations. Also important is challenging romanticized accounts of triumphant heroes coming home by giving explicit recognition to the all too common compromised marital relationships, alienated children, resentment, and betrayal.

Regarding government policy, programs such as dual citizenship, travel security, and remittance regulations can be formulated in ways that support transnational families. Such programs can benefit by giving more explicit recognition to consumption as a mechanism for family and national development. Especially in developing nations, local governments and community organizations leverage remittances in developing education, health care, infrastructure, etc., and yet public policy makers must look beyond remittances to the types of consumption they foster, viewing family members at home as vital development agents fulfilling an important role in helping foster growth and opportunity in their consumption of foods, health care, and housing to provide valuable jobs to enable people to make their lives in Mexico.

Regarding limitations, this work features the consumption experiences of Mexican transnational families through the eyes of those remaining at home. While telling in some ways, as this is the manner in which many live their lives on a day-to-day basis, missing are the insights and perspectives of migrant family members. Second, this work gives a fairly systematic account of transnational family consumption which trades breadth for depth regarding individual and family characteristics, transnational cultural/economic domains, consumption activities, processes and meanings, and their impacts. Thus, the findings are more suggestive of the range of these consumption phenomena and their impacts than exhaustive.

It is expected that this research will stimulate further research into the processes and impacts of transnational family consumption in Mexico and in other nations. Further work could feature the perspectives of migrants working in the U.S. together with those family members in Mexico, with an eye to similarities and differences in their views and experiences. Further work might explore dynamics of consumer socialization within transnational 
families, extending this body of work beyond families living within one cultural domain (Roedder-John, 1999) to appreciate the negotiation of changing cultural associations for products and services here, there, and beyond as a complex interweaving of family hopes, dreams, and obligations in consumption. The microdynamics of cultural power between the codes and practices in Mexico, in the U.S., and beyond, negotiations of gender roles for men, women, and adolescent migrants, and the long term place of consumption in nuclear and extended families that reunite are promising areas of further study. Further work has to examine transnational family consumption in the current economic crisis. Initial reports show a significant decline in remittance amounts and the return of many emigrant workers (Bertossi, 2008). Such migrant moves portend yet another cycle of family adaptation as challenging as that documented here.

\section{References}

Anderson, B. (|99|). Imagined Communities: Reflections on the Origin and Spread of Nationalism. New York:Verso.

Askegaard, S., E. J. Arnould \& D. Kjeldgaard (2005). "Postassimilationist Ethnic Consumer Research: Qualifications and Extensions". Journal of Consumer Research, 32 (I), June, I60-170.

Bates, M. J. \& J.W. Gentry (1994). "Keeping the Family Together: How We Survived the Divorce", in Chris T. Allen \& Deborah Roedder John. Advances in Consumer Research. 2 $\mathrm{I}^{\text {st }}$ ed. Provo: Association for Consumer Research, 30-34.

Bertossi, C. (2008). “Immigration: le rendez-vous européen manqué”. Libération, I 0-I I, January, 28.

Bourdieu, P. (1986). “The Forms of Capital”, in Handbook of Theory and Research for the Sociology of Education. New York: Greenwood Press, 24I-258.

British Broadcasting Corporation News (2009).Slowdownhits Mexico Remittances. Available at: http://news.bbc.co.uk/2/hi/business/785502I.stm [May 16].

Bryceson, D. \& U.Vuorela (eds.) (2002). The Transnational Family: New European Frontiers and Global Networks. Oxford, UK: Berg. 
Castles, S. \& M. J. Miller (2003). The Age of Migration. New York: Guilford Publications.

Conapo (2000). Geografia de la migración México-Estados Unidos (MexicoUSA Migration Geography). Mexico: Consejo Nacional de Población. Available at: http://www.conapo.gob.mx/publicaciones/ intensidadmig/cap04.pdf

Cross, S. (2008). "For Better or For Worse: The Intersection of Cultures in Bi-National Homes". Advances in Consumer Research, 35, I62-I65.

Drainville, A. C. (2002). "The Fetishism of Global Civil Society: Global Governance, Transnational Urbanism and Sustainable Capitalism in the World Economy", in Michael Peter Smith \& Luis Eduardo Guarnizo (eds.). Transnationalism from Below. New Brunswick: Transaction Publishers, 35-63.

Epp, A. \& L. Price (2008). "Family Identity: A Framework of Identity Interplay in Consumption Practices". Journal of Consumer Research, 35, June, $50-70$.

Falicov, C. (2005). "Emotional Transnationalism and Family Identities”. Family Process, 44 (4), 399-406.

Garlarza, E. (1964). Merchants of Labor:The Mexican Bracero Story; an Account of Time Managed Migration of Mexican Farm Workers in California, 19421960. Charlotte: McNally \& Loftin.

Ger, G.\& R. Belk (1996).“'l'd like to Buy the World a Coke: Consumptionscapes of the less Affluent World". Journal of Consumer Policy, 19 (3), September, 27I-304.

Goldring, L. (2002). “The Power of Status in Transnational Social Fields”, in M. P. Smith \& L. E. Guarnizo (eds.). Transnationalism from Below. New Brunswick:Transaction Publishers, 165-195.

Grewal, I. \& C. Kaplan (eds.) (1994). Scattered Hegemonies: Postmodernity and Transnational Feminist Practices. Minneapolis: University of Minnesota Press.

Hirsch, J. S. (2003). A Courtship after Marriage: Sexuality and Love in Mexican Transnational Families. Berkeley: University of California Press.

Holt, D. (1997). "Poststructuralist Lifestyle Analysis: Conceptualizing the Social Patterning of Consumption in Postmodernity". Journal of Consumer Research, March, 326-350. 
Kalir, B. (2005). "The Development of a Migratory Disposition: Explaining a ‘New Emigration'”. International Migration, 43 (4), I67-I 94.

Kennedy, P. \& V. Roudometof (eds.) (2002). Communities across Borders: New Immigrants and Transnational Cultures. London: Routledge.

Kjeldgaard, D. \& S. Askegaard (2006). "The Globalization of Youth Culture: The Global Youth Segment as Structures of Common Difference". Journal of Consumer Research, 33 (2), 23I-247.

Lapper, R. (2007). “Globalization's Exiles Keep the Home Fires Burning”. Financial Times, August 28, 7.

Lindridge, A., M. Hogg \& M. Shah (2004). "Imagined Multiple Worlds: How South Asian Women in Britain use Family and Friends to Navigate the Border Crossings between Household and Societal Contexts". Consumption, Markets, Culture, 7 (3), 2 I I-238.

Lofland,J., et al. (2006). Analyzing Social Settings.A Guide to Qualitative Observation and Analysis. Belmont:Thomson Wadsworth.

Mahler, S. (2002). "Theoretical and Empirical Contributions: Towards a Research Agenda for Transnationalism”, in Michael Peter Smith \& Luis Eduardo Guarnizo (eds.). Transnationalism from Below. New Brunswick:Transaction Publishers, 64-100.

Miller, D. (1998). A Theory of Shopping. London: Polity Press.

Oswald, L. (1999). "Culture Swapping: Consumption and Ethnogenesis of Middle Class Hatian Immigrans". Journal of Consumer Research, 25, 303-318.

Papail, J. (2002). "De asalariado a empresario: la reinserción laboral de los migrantes internacionales en la región centro-occidente de México (The international migrant labor reinsertion in the central-west region of Mexico)". Migraciones Internacionales, I (3), 79- 102.

Parella, S. (2007). "Los vínculos afectivos y de cuidado en las familias transnacionales. Migrantes ecuatorianos y peruanos en España”. Migraciones Internacionales, 4 (2), I 5 | - I88.

Parreñas, R. (2005). Children of Global Migration:Transnational Families and Gender Woes. Stanford, CA: Stanford University Press.

Peñaloza, L. (1994). "Atravesando fronteras/Border Crossings: A Critical Ethnographic Exploration of the Consumer Acculturation of Mexican Immigrants". Journal of Consumer Research, 2 I (I), June, 32-54. 
(1995). "Immigrant Consumers: Marketing and Public Policy Considerations in the Global Economy". Journal of Public Policy \& Marketing, I 4 (I), 83-94.

Poster, M. (1978). Critical Theory of the Family. New York: Seabury Press.

Roedder-John, D. ( 1999). “Consumer Socialization of Children:A Retrospective Look at Twenty-five Years of Research". Journal of Consumer Research, 26 (3), I83-2I3.

Rouse, R. ( 1992).“Making Sense of Settlement: Class Transnationalism Cultural Struggle and Transformation among Mexican Migrants in the United States". Annals of the New York Academy of Science, 645, 25-52.

Schmalzbaur, L. (2005). Striving and Saving: A Daily Life Analysis of Honduran Transnational Families. New York: Routledge.

Sen, A. ( 1999). Development as Freedom. New York:Alfred Knopf.

Sherry, J. \& E. Fischer (2009). Explorations in Consumer Culture Theory. London:

Routledge.

Smith, M. P. \& L. E. Guarnizo (eds.) (2002). Transnationalism from Below. New Brunswick:Transaction Publishers.

Smith, R. C. (2006). Mexican New York:Transnational Lives of New Immigrants.

Berkeley: University of California Press.

Suárez-Orozco, C., I. Todorova \& J. Louie (2002). “Making Up For Lost Time:

The Experience of Separation and Reunification Among Immigrant

Families". Family Process, 4I (4), 625-643.

Suro, R. (2003). Remittance Senders and Receivers:Tracking the Transnational

Channels. Washington, D. C.: Pew Hispanic Center. November 24.

Available at: http://pewhispanic.org/file/reports/23.pdf

Thompson, C. \& S. K. Tambyah (1999). “Trying to be Cosmopolitan”. Journal of Consumer Research, 26 (3), 2 I4-24I.

Üçok, M. (2007). Consumption Practices in Transnational Social Spaces:A Study of Turkish Transmigrants in Denmark. Doctoral dissertation. Odense: University of Southern Denmark.

Üstüner, T. \& D. Holt (2007). “Dominated Consumer Acculturation:The Social Construction of Poor Migrant Women's Consumer Identity Projects in a Turkish Squatter". Journal of Consumer Research, 34 (I), $4 \mid-56$. 
Visconti, L. (2006). Border Crossing Consumers and Postassimilationist Studies:

Cultural Alternation in the Marketplace.Working Paper. Milan: Bocconi University. 


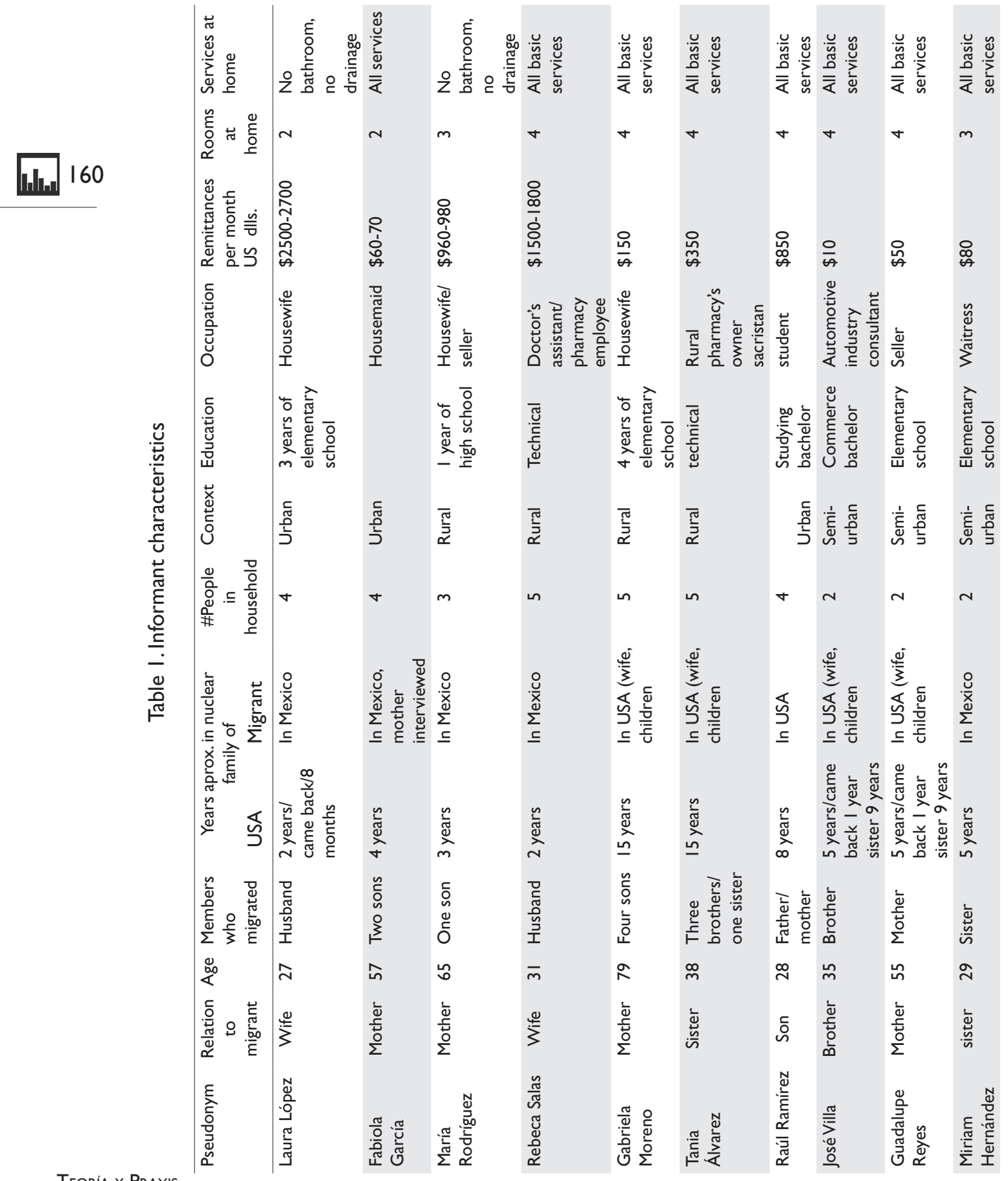


Figure I. Conceptualizing transnational family consumption

\section{Transnational / Cultural/ Economic \\ Domains}

\section{Family}

Features

\author{
Processes \\ Activities

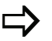 \\ and \\ Meanings
}

Member

Characteristics:

Relationship, Sex/

Gender,Age,

Education,

Occupation

\section{United States}

More labor

opportunities

Higher levels of consumption

Financial gain, Family sacrifices

\section{Beyond}

Cultural juxtaposition, comparisons,

hopes, and dreams

Family/

Household

Composition,

Nuclear and

Extended

Living

Arrangements

Neighborhood, Community Relations

\section{Remittance \\ Amounts \\ Timing}

Circulating money. Products and services

Provisioning Travel, Food, Healthcare, Clothing, Entertainment

Purveying family weddings, funerals, Return fiestas

Saving and Autos, Houses, Businesses, Loans to Family

\section{Resource Generation, Translation, Integration, Conflict} events: birthdays, Investing: Currency, and Friends

Supporting Community Events and Development
Personal resource and meaning quest with growth and setbacks

Family love and intimacy, Togetherness at a distance, Caregiving, Sharing resources, and Compromising For security, well-being and Happiness

\section{Community} connectedness, Making home in Mexico
Migrant as heroic provider, Family members as beneficiaries pushing migration

Culturally sanctioned family form Modifies activities and gender roles Improves quality of life,

Enhances

financial security, Strengthens and weakens family ties, Shifts time and space orientation, Augments and diminishes hopes for the future.

Repositions family in community, Diffuses local and federal government responsibilities, Fosters international interdependency, Sustains myth of El Norte 
